\title{
CARDIOTOXICITY STUDY OF THE AQUEOUS EXTRACT OF CORN SILK IN RATS
}

\author{
Adeolu Adedapo ${ }^{1}$, Omotayo Babarinsa ${ }^{1}$, Ademola Oyagbemi $^{1}$, \\ Aduragbenro Adedapo ${ }^{2}$, Temidayo Omobowale ${ }^{3}$ \\ ${ }^{1}$ Department of Veterinary Physiology, Biochemistry and Pharmacology, \\ University of Ibadan, Ibadan, Nigeria \\ ${ }^{2}$ Department of Pharmacology and Therapeutics, University of Ibadan, Ibadan, Nigeria \\ ${ }^{3}$ Department of Veterinary Medicine, University of Ibadan, Ibadan, Nigeria
}

Received 20 July 2015; Received in revised form 5 November 2015; Accepted 10 November 2015

\begin{abstract}
In the ear of corn there are silky strands which run its length and these strands are known as corn silks. Folk remedies show that the corn silks have been used as an oral antidiabetic agent in China for many years and as herbal tea in other world nations for the amelioration of urinary tract infection. The extract is being assessed for safety in this study using histopathological changes, as well as an electrocardiogram (ECG). Graded doses $(200,400$ and $800 \mathrm{mg} / \mathrm{kg}$ ) of aqueous CS extract were administered to rats for seven days. The fourth group which served as control received $3 \mathrm{ml} / \mathrm{kg}$ dose of distilled water. On the eighth day, ECG was evaluated in ketamine/xylazine-induced anaesthesia in rats to determine changes in the heart rate, P-wave duration, P-R interval, R-amplitude, QRS duration, QT interval and QTc. Hearts from the experimental animals were collected for histopathological changes. The results showed that there was a significant change in the heart rate (groups B and C), P-wave duration (group D), QT interval (groups B, C and D) and QTc (groups B, C and D) when compared to the control group. Histology also indicated that sections of the heart showed fatty infiltration of inflamed heart and areas of moderate inflammation of the atrium and ventricle. It could therefore be concluded from this study that though folklore indicated that corn silk (CS) is of high medicinal value, one must be careful in using this product as medicinal agent especially in patients with compromised heart conditions.
\end{abstract}

Key words: corn silks, ECG, histopathology, cardiotoxicity, rats

\section{INTRODUCTION}

Applications of complementary and alternative medicine have gained some prominent attention in recent times due to the fact that these form of medicine offer great opportunities in the discovery, development and production of potent, safe and inexpensive alternatives to existing synthetic chemotherapeutic agents $(1,2)$. Many of the plants with medicinal values have been used in different cultures of the world to treat many diseases and

Corresponding author: Dr. Adeolu Adedapo, $\mathrm{PhD}$

E-mail address: aa.adedapo@ui.edu.ng

Present address: Department of Veterinary Physiology, Biochemistry and Pharmacology, Faculty of Veterinary Medicine,

University of Ibadan, Nigeria

Phone: +2348162746222

Copyright: (C) 2015 Adedapo A. This is an open-access article published under the terms of the Creative Commons Attribution License which permits unrestricted use, distribution, and reproduction in any medium, provided the original author and source are credited.

Competing Interests: The authors have declared that no competing interests exist.

Available Online First: 20 November 2015

Published on: 15 March 2016

http://dx.doi.org/10.1515/macvetrev-2015-0065 infections and drugs obtained from plant sources have been in use for a while now. In fact, rural dwellers used these herbs as therapeutic agents and medicament because they could procure them easily (3). It is on record that plants have provided a source of knowledge with respect to novel drug compounds because medicinal products obtained from plants have made tremendous contributions to human health and well being (4). One such plant-derived product is corn silk.

Corn silks look like strands of hair that are initially green in colour, then become red, and finally turn yellow. Corn silk threads may be steeped in boiling water to make tea. It has a variety of health benefits as it contains moderate amount of iron, potassium, zinc, phosphorus, magnesium and calcium. Corn silk tea may improve urinary tract infection and kidney stones (5). It is also known to be rich in proteins, vitamins, carbohydrates, fixed and volatile oils, steroids (such as sitsterol, stigma sterol, alkaloids, saponins, tannins) and flavonoid 
(6). Folk remedies show that corn silk has been used as an oral antidiabetic agent in China for decades, but the mechanism of its hypoglycaemic activity has not been elucidated (7). Corn silk has been used as tea for its diuretic properties, especially that it may help soothe irritation in the urinary system. Again, corn silk when used in conjunction with other herbs may help treat health conditions such as mumps or inflammation of urinary bladder or urethra (5). For those that suffer from high blood pressure, corn silk tea may be a gentle and natural way to help lower blood pressure. Because this tea is safe and gentle on the body, it makes it a preferred method for lowering high blood pressure as opposed to some over the counter medications which can come with some unexpected and unwanted side effects. Finally, it can keep blood pressure from dropping undesirably low as well, which makes this advantage useful for those that suffer from diabetes (6).

In this study, the aqueous extract of the corn silk was evaluated for safety or otherwise, especially because ethnomedicinal surveys have shown that its herbal tea is said to possess a lot of medicinal potential.

\section{MATERIAL AND METHODS}

Collection of fresh maize leaves and maize silk

Fresh corns with intact corn silk were collected from the Ayo farm in Abeokuta, Ogun State, Nigeria in June, 2014. After collection, the corn silks were dried for a few days and afterward pulverized in an electric blender into powdery form. It was the local maize variety that was used in this study.

\section{Preparation of aqueous extract of maize silk}

Each of the pulverized substances were soaked with $1000 \mathrm{ml}$ of distilled water in a separate conical flask for 48 hours and then filtered. The filtrate was then concentrated using rotary evaporator and steam bath to obtain an aqueous extract. The extract was stored in refrigerator until its use for biological activities.

\section{Experimental animals}

Twenty healthy white strain albino female rats $(100-140 \mathrm{~g})$ and thirty male mice (12 $25 \mathrm{~g}$ ) used in this study were obtained from the Experimental Animal House of the Faculty of Veterinary Medicine, University of Ibadan, Nigeria. The animals were kept in cages within the animal house and allowed free access to water and standard livestock pellets. The animals were examined and found to be free of wounds, swellings and infections 44 before the commencement of the experiment. All experimental protocols were conducted as directed by the National Institute of Health Guide for Care and Use of Laboratory Animals.

\section{Chemicals and drugs}

The chemicals and drugs which were used include the following: Normal saline, distilled water, Formalin, xylazine and Ketamine.

Acute toxicity of the aqueous extract of corn silk

The acute toxicity study of maize silk was conducted in line with the method of Sawadogo et al (8). Briefly, thirty male mice fasted for 16 hours were randomly divided into 6 groups of 5 animals each. Graded doses of the aqueous extract (200, $400,800,1,600$ and 3,200 $\mathrm{mg} / \mathrm{kg}$ ) corresponding to groups $\mathrm{B}, \mathrm{C}, \mathrm{D}, \mathrm{E}, \mathrm{F}$, and $\mathrm{G}$ respectively were separately administered to the mice in each test group using oral cannula. The control group or group A was administered with distilled water $(3 \mathrm{ml} /$ $\mathrm{kg}$ ) only. All animals were then given access to feed and water ad libitum and thereafter observed for a period of 48 hours for signs of acute toxicity, morbidity and mortality.

\section{Sub acute toxicity of the aqueous extract of corn} silk in rats

The sub acute toxicity study of maize silk was also carried out according to the method of Sawadogo et al (8). Twenty female rats were randomly divided into 4 groups of 5 animals each. Graded doses of the extract $(200,400$ and $800 \mathrm{mg} / \mathrm{kg}$ ) representing groups $\mathrm{B}, \mathrm{C}$, and $\mathrm{D}$ respectively were separately administered to the rats in each test group using oral cannula. The control group or group A was administered with distilled water $(3 \mathrm{ml} / \mathrm{kg})$ only. All animals were given feed and water ad libitum and thereafter observed for signs of toxicity, morbidity and mortality. The administration of the extract and distilled water was for 7 days only.

Electrocardiography (ECG) evaluation of rats administered with aqueous extract of corn silk

ECG of all the animals used for the evaluation of sub-acute toxicity was measured on the eight day i.e. 24 hours after the sub-acute toxicity was concluded. The rats were anaesthetized with $0.1 \mathrm{ml} / 100 \mathrm{~kg}$ of ketamine/xylazine (v/v) to aid stabilization and the five electrodes of the ECG machine were placed at the appropriate position (both fore limbs, both hind limbs and chest). Hair was clipped to improve contact between the ECG pad and the skin. Electrode gel was used to improve contact between the patient 
and electrodes. The electrodes were connected to the ECG machine by colour-coded cables. The ECG was recorded in a calm and quiet environment. Standard lead II electrocardiogram was recorded in conscious rats using a 7-lead ECG machine (EDAN VE-1010, Shanghai, China). The machine was calibrated at $20 \mathrm{~mm} / \mathrm{mV}$ paper speed and $50 \mathrm{~mm} / \mathrm{s}$ paper speed. From the electrocardiogram, parameters such as heart rate, P-wave, QT, QTc etc were determined.

\section{Histopathology}

After the ECG measurement was concluded, all the animals used for the sub-acute toxicity study were sacrificed by over-dose of chloroform anaesthesia. The hearts from these animals were removed and placed in $10 \%$ formalin in normal saline for histological studies. These isolated organs were placed in an automatic tissue processor for 24 hrs and after these, the tissues were solidified in molten wax and sectioned using automatic tissue sectioner, fixed on slides with haematoxylin and eosin and thereafter stained slides were fixed with mountant, allowed to dry and viewed under the microscope (x400).
Statistics

All values were expressed as mean \pm S.D. The test of significance between two groups was estimated by Student's t test. "One-way ANOVA" with Dunnett's post-hoc test was also performed using GraphPad software version 4.00.

\section{RESULTS}

\section{Acute toxicity study}

In the acute toxicity test, no death was recorded in all the groups. All the mice appeared to be normal and none of them showed any visible signs of toxicity.

\section{$E C G$}

The electrocardiographs taken are represented in graph pads (Fig. 1-7) below. Group A - Control, Group B, Group C and Group D. There was significant change in heart rate (groups B and C), $\mathrm{P}$-wave duration (group D), QT interval (groups B, C and D) and QTc (groups B, C and D) when compared to the control group.

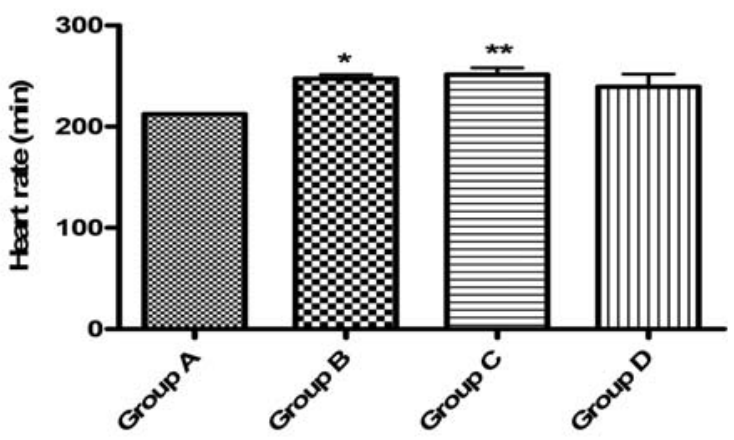

Figure 1. Heart rate (min). Asterisks $(*)$ and $(* *)$ represented significant differences at $\mathrm{p}<0.05$ and $\mathrm{p}<0.01$ respectively when compared with the control (Group A)

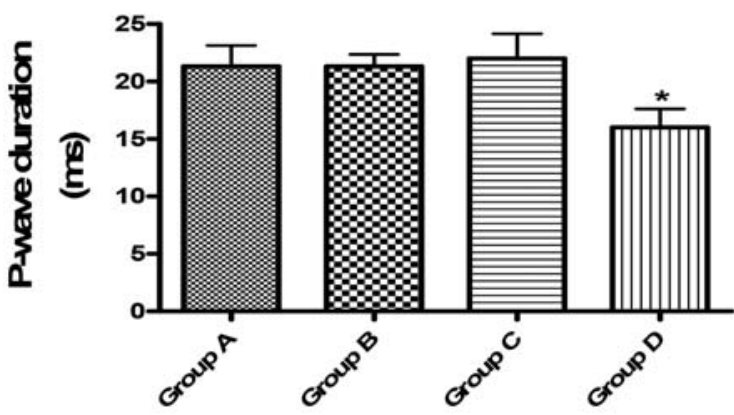

Figure 2. P-wave duration (ms). Asterisks (*) represented significant differences at $\mathrm{p}<0.05$ when compared with Group A

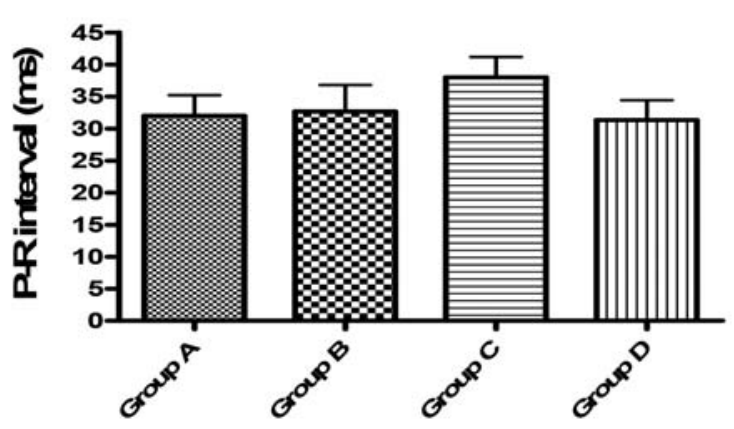

Figure 3. P-R interval (ms). No significant difference at $p<0.05$ was observed in this parameter when compared with Group A

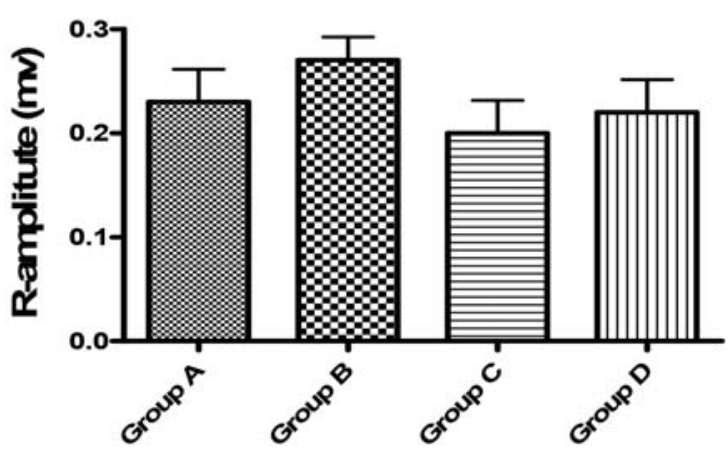

Figure 4. R-amplitude (mv). No significant difference at $\mathrm{p}<0.05$ was shown in this parameter when compared with the control (Group A) 


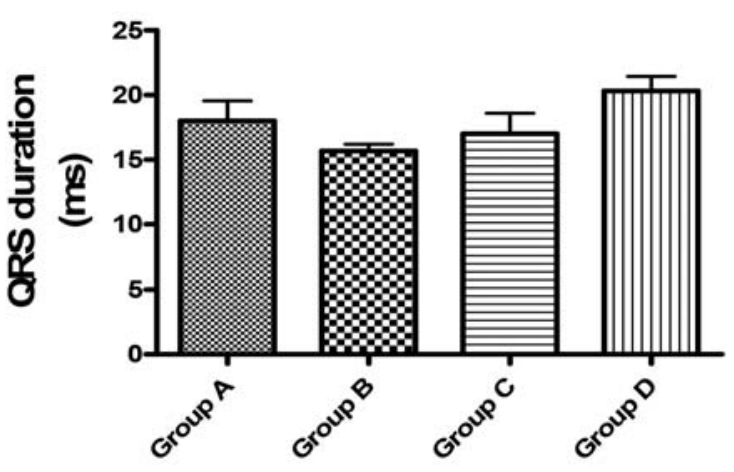

Figure 5. QRS duration (ms). No significant difference at $\mathrm{p}<0.05$ was shown in this parameter when compared with the control (Group A)

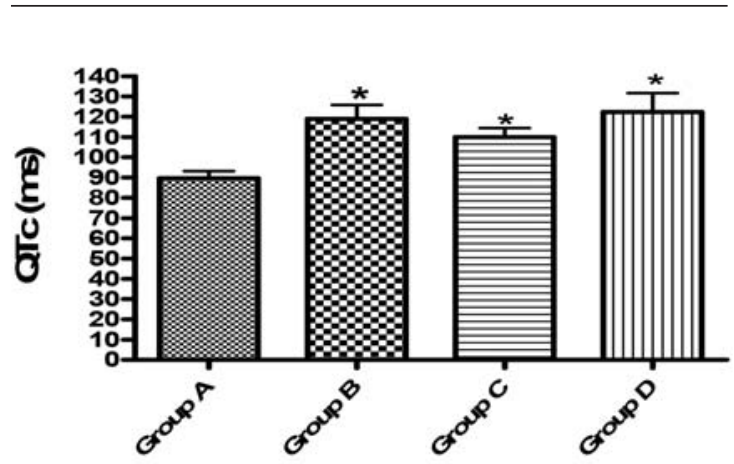

Figure 7. QTc (ms). Asterisks (*) indicates significant difference at $\mathrm{p}<0.05$ when compared with the control (Group A)

\section{Histopathology}

Histological examination of the heart indicated that the extract caused pathological changes in this organ. For instance, the heart sections showed fatty infiltration of inflammed heart and areas of moderate inflammation of the atrium and ventricle. These observations are as depicted in the photomicrographs depicted below (Fig. 8a-d).

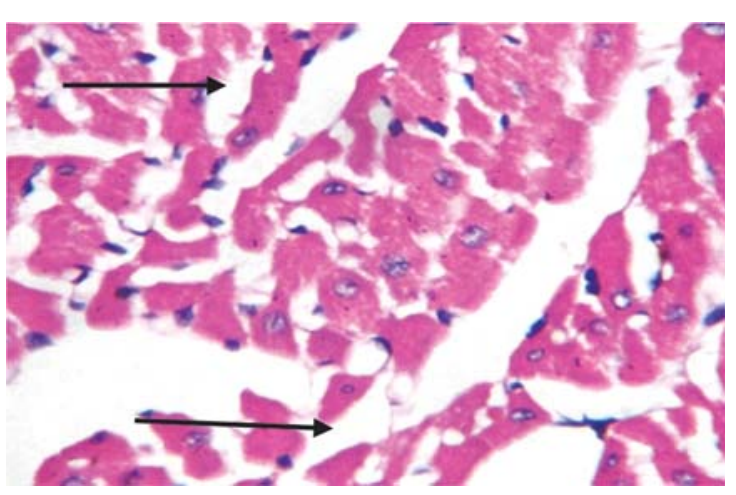

Figure 8a. Heart: Sections show fatty infiltration of inflammed heart of group B animal (X400)

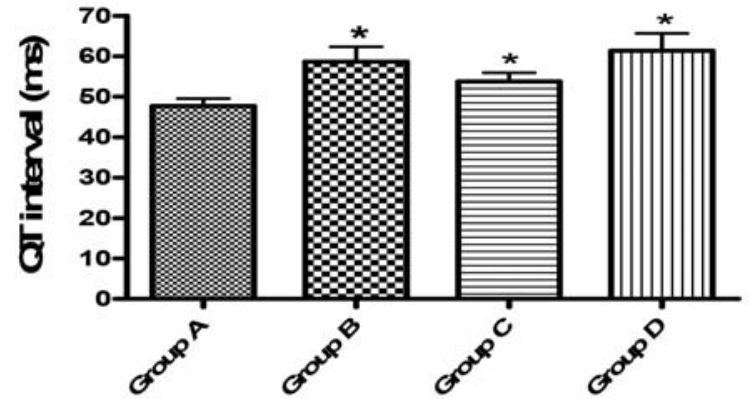

Figure 6. QT interval (ms). Asterisks (*) showed significant difference at $\mathrm{p}<0.05$ when compared with the control (Group A)

\section{DISCUSSION}

Corn silk made from stigmas, is often a waste material from the cultivation of corn and is usually present in large quantities (9). In countries such as China, Turkey, United States and France, corn silk is used traditionally for the treatment of cystitis, edema, kidney stones, diuretic, prostate disorder, and urinary infections as well as bedwetting and obesity $(10,11,12,13,14,15)$. The mechanism of action may be related to the fact that it soothes and relaxes the lining of the bladder and urinary tubules, thereby reducing irritation and increasing urine secretion (16). The use of CS in traditional medicine has also showed that it has anti-fatigue, antidepressant and kaliuretic activities $(15,17,18)$. In addition to these properties, CS possesses excellent antioxidant activity $(7,19)$ and demonstrated radiation-protective as well as nephroprotective effects $(20,21)$. These excellent activities of CS prompted our need to evaluate it for safety in laboratory animals such as mice and rats.

The acute toxicity study showed that the aqueous extract of CS is safe for use medicinally because the $3200 \mathrm{mg} / \mathrm{kg}$, the highest dose used in this study did not produce any lethal change in mice especially that the animals appeared normal and no mortality was recorded. This observation of safety in acute toxicity was similar to that of Ambike et al (22) who also observed that at $3.2 \mathrm{gm} / \mathrm{kg}$, the aqueous extract of corn silk was safe for medicinal use. The lack of toxicity even up to $3200 \mathrm{mg} /$ dose of this extract guided our choice of doses in the sub acute toxicity study in which the extract was administered to rats for seven days and then examined for any toxic changes in the heart tissues using ECG and histopathology as indices of toxicosis.

In the ECG study, there was a significant change in heart rate (groups B and C), P-wave duration (group D), QT interval (groups B, C and D) and QTc 


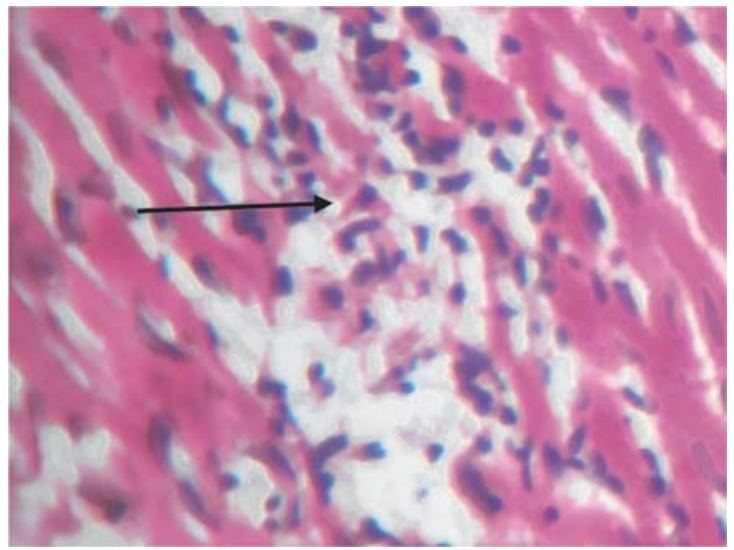

Figure 8b. Heart: Sections show focal area of inflammation (black arrow) in group C (X400)

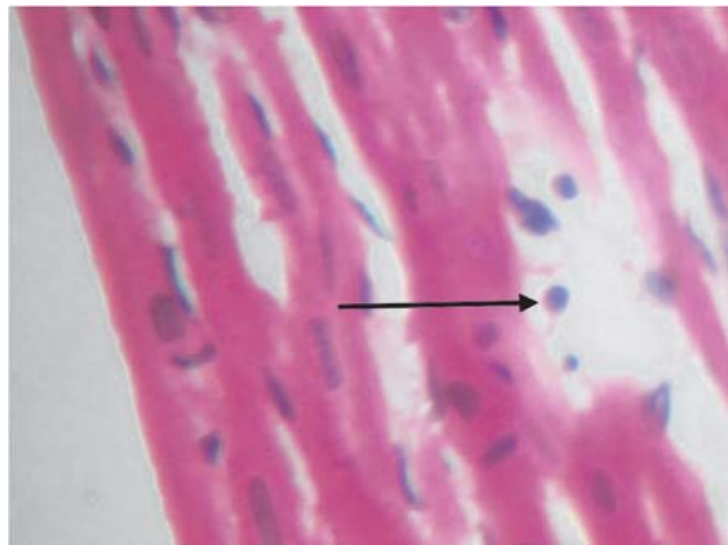

Figure 8c. Heart: Sections show area of infiltration by inflammatory cells (black arrow) in group C (X400) (groups B, C and D) when compared to the control group. Administration of the extract to the rats for seven days thus led to increase in the heart rate for the animals in groups B and C, but not in group D (the highest dose $-800 \mathrm{mg} / \mathrm{kg}$ ) in this study. The study thus showed that administration of the extract led to tachycardia in groups $\mathrm{B}$ and $\mathrm{C}$ animals. Tachycardia which is a fast heart rate (more than 100 beats per minute in humans) indicated that at these elevated rates, the heart is not able to efficiently pump oxygen-rich blood to the body. It also shows that at this condition of increased heart rate there may be increased work and oxygen demand by the heart, and as a result, there may be the development of rate related ischemia $(23,24,25,26,27)$.

The P-wave represents depolarization of the atria and when it is of unusually long duration, it may be an evidence of atrial enlargement. In the present study, there was a shortening of $\mathrm{P}$-wave duration (PWD) in group D animals. It was reported that shorter baseline PWD may be a pointer of a lower risk of persistent atrial fibrillation (AF) that may require cardioversion or AF-related hospitalization (28). It thus showed that the shortening of P-wave by the extract in this study is an indication of its having a cardiotonic effect on the heart. The QT interval is usually measured from the beginning of the QRS complex to the end of the T wave. When QTc interval is prolonged, it may become a risk factor for ventricular tachyarrhythmias and sudden death. This condition can arise as a genetic syndrome, or may be as a side effect of certain medications, but, an unusually short QTc can be seen in severe hypercalcemia $(29,30,31,32)$. In this study, all the tested doses brought about an increase in QT and QTc interval. It thus showed that the use of the extract for medicinal purposes is fraught with danger, hence cardiotoxicity. It must be noted that this is the first time that an ECG recording of the effect of corn silk extract in rats is being recorded.

Histological examination of the heart in this study corroborated the cardiotoxic changes brought
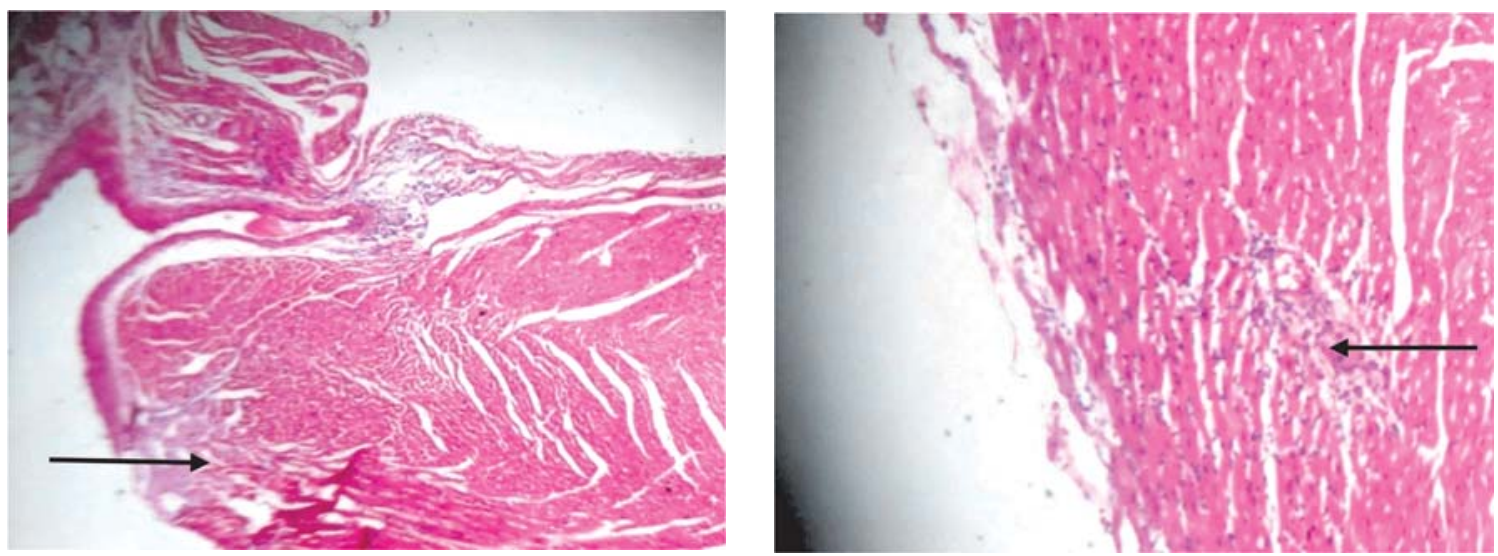

Figure 8d. Heart: Sections show focal areas of moderate inflammation of the atrium and ventricle (black arrows) in group D (X40; X100). 
about with the use of this extract. Fatty infiltration of inflammed heart and areas of moderate inflammation of the atrium and ventricle were observed in this study in the tested groups. This histological change is similar to findings in arrhythmogenic right ventricular dysplasia/cardiomyopathy (33).

It could then be concluded from this study that lots of caution should be put in place when using this corn silk for medicinal purposes most especially in patient with compromised heart health condition.

\section{ACKNOWLEDGEMENT}

The study was carried out with the assistance of the University of Ibadan Senate Research grant (SRG/ FVM/2010/10A) given to Dr. Adedapo.

\section{REFERENCES}

1. Rao, NK., Nammi, S. (2006). Antidiabetic and renoprotective effects of the chloroform extract of Terminalia chebula Retz. seeds in streptozotocininduced diabetic rats. BMC Complement Altern Med. $6,17$.

http://dx.doi.org/10.1186/1472-6882-6-17

PMid:16677399 PMCid:PMC1540439

2. Aloulou, A., Hamden, K., Elloumi, D., Ali, MB., Hargafi, K., Jaouadi, B., Ayadi, F., Elfeki, A., Ammar, E. (2012). Hypoglycemic and antilipidemic properties of kombucha tea in alloxan-induced diabetic rats. BMC Complement Altern Med. 12, 63.

http://dx.doi.org/10.1186/1472-6882-12-63

PMid:22591682 PMCid:PMC3403982

3. Bhagwat, DA., Killedar, SG., Adnaik, RS. (2008). Anti-diabetic activity of leaf extract of Tridax procumbens. Intl J Green Pharm. 2, 126-128. http://dx.doi.org/10.4103/0973-8258.41188

4. Saha, S., Verma, RJ. (2012). Efficacy study of Dolichos biflorus in the management of nephrotoxicity. Asian Pac J Trop Biomed. S1471-S1476.

http://dx.doi.org/10.1016/S2221-1691(12)60440-7

5. Guo, J., Liu, T., Han, L., Liu, Y. (2009). The effects of corn silk on glycaemic metabolism. Nutr Met. 6, 47. http://dx.doi.org/10.1186/1743-7075-6-47 PMid:19930631 PMCid:PMC2785813

6. Hasanudin, K., Hashim, P., Mustafa, S. (2012). Corn silk (Stigma maydis) in healthcare: a phytochemical and pharmacological review. Molecules 17, 9697-9715.

http://dx.doi.org/10.3390/molecules17089697

PMid:22890173

7. Ebrahimzadeh, MA., Pourmorad, F., Hafezi, S. (2008). Antioxidant activities of Iranian corn silk. Turk J Biol. 32, 43-49.
8. Sawadogo, WR., Boly, M., Lompo, M., Some, N. (2006). Anti-inflammatory, analgesic and antipyretic activities of Dicliptera verticillata. Intl J Pharmacol. 2, 435-438.

http://dx.doi.org/10.3923/ijp.2006.435.438

9. Maksimović, Z., Malenčić, Đ., Kovačević, N. (2005). Polyphenol contents and antioxidant activity of Maydis stigma extracts. Bioresource Technol. 96, 873-877.

http://dx.doi.org/10.1016/j.biortech.2004.09.006 PMid: 15627557

10. Bastien, JW. (1982). Pharmacopeia of qollahuayaandeans. J Ethnopharmacol. 8, 97-111. http://dx.doi.org/10.1016/0378-8741(83)90091-0

11. Caceres, A., Giron, LM., Martinez, AM. (1987). Diuretic activity of plants used for the treatment of urinary ailments in Guatemala. J Ethnopharmacol. 19, 233-245. http://dx.doi.org/10.1016/0378-8741(87)90001-8

12. Dat, DD., Ham, NN., Khac, DH., Lam, NT., Son, PT., Dau, NV., Grabe, M., Johansson, R., Lindgren, G., Stjernstrom, NE. (1992). Studies on the individual and combined diuretics effects of four Vietnamese traditional herbal remedies (Zea mays, Imperata cylindrica, Plantago major and Orthosiphon stamineus). J Ethnopharmacol. 36, 225-231. http://dx.doi.org/10.1016/0378-8741(92)90048-V

13. Grases, F., March, JG., Ramis, M., Costa-Bauzá, A. (1993). The influence of Zea mays on urinary risk factors for kidney stones in rats. Phytother Res. 7, 146-149.

http://dx.doi.org/10.1002/ptr.2650070210

14. Yesilada, E., Honda, G., Sevik, E., Tabata, M., Fujita, T., Tanaka, T., Takeda, Y., Takaishi, Y. Traditional medicine in Turkey. V. (1995). Folk medicine in the inner Taurus Mountains. J Ethnopharmacol. 46, 133-152. http://dx.doi.org/10.1016/0378-8741(95)01241-5

15. Hu, QL., Zhang, LJ., Li, YN., Ding, YJ., Li, FL. (2010). Purification and anti-fatigue activity of flavonoids from corn silk. Intl J Phys Sci. 5, 321-326.

16. Steenkamp, V. (2003). Phytomedicines for the prostate. Fitoterapia 74, 545-552. http://dx.doi.org/10.1016/S0367-326X(03)00155-2

17. Velazquez, DVO., Xavier, HS., Batista, JEM., Castro-Chaves, CD. (2005). Zea mays L. extracts modify glomerular function and potassium urinary excretion in conscious rats. Phytomed. 12, 363-369. http://dx.doi.org/10.1016/j.phymed.2003.12.010 PMid:15957371

18. Ebrahimzadeh, MA., Mahmoudi, M., Ahangar, N., Ehteshami, S., Ansaroudi, F., Nabavi, SF., Nabavi, SM. (2009). Antidepressant activity of corn silk. Pharmacologyonline 3, 647-652. 
19. Maksimovic, ZA., Kovačević, N. (2003). Preliminary assay on the antioxidative activity of Maydis stigma extracts. Fitoterapia 74, 144-147.

http://dx.doi.org/10.1016/S0367-326X(02)00311-8

20. Bai, H., Hai, C., Xi, M., Liang, X., Liu, R. (2010). Protective effect of maize silks (Maydis stigma). Ethanol extract on radiation-induced oxidative stress in mice. Plant Food Hum Nutr. 65, 271-276. http://dx.doi.org/10.1007/s11130-010-0172-6 PMid:20526679

21. Sepehri, G., Derakhshanfar, A., Zade, FY. (2011). Protective effects of corn silk extract administration on gentamicin-induced nephrotoxicity in rat. Comp Clin Pathol. 20, 89-94. http://dx.doi.org/10.1007/s00580-009-0943-3

22. Ambike, AA., Khandelwal, KR., Bodhankar, SL., Kadam, SS. (2000). Toxicity study and diuretic activity of corn silk, Zea mays L. Indian J Pharmacol. 32, 132-175.

23. Oosting, J., Struijker, BH., Janssen BJ. (1997). Autonomic control of ultradian and circadian rhythms of blood pressure, heart rate, and baroreflex sensitivity in spontaneously hypertensive rats. J Hypertens. 15, 401-410.

http://dx.doi.org/10.1097/00004872-199715040-00011 PMid:9211175

24. Carvalho, MJ., van Den Meiracker, AH., Boomsma, F., Lima, M., Freitas, J., Veld, AJ., Falcao, DF. (2000). Diurnal blood pressure variation in progressive autonomic failure. Hypertens. 35, 892-897. http://dx.doi.org/10.1161/01.HYP.35.4.892

25. Custer, JW., Rau, RE. eds. (2008). Johns Hopkins: The Harriet Lane Handbook. 18th ed. Philadelphia, PA: Mosby Elsevier Inc.

26. Fauci, AS., Braunwald, E., Kasper, DL., Hauser, SL., Longo, DL., Jameson, JL., Loscalzo J. (2008). Harrison's Principles of Internal Medicine, 17th Edition. Amazon.com, Inc.
27. Moyer, VA. (2012). Screening for coronary heart disease with electrocardiography: U.S. Preventive Services Task Force recommendation statement. Annals Intern Med. 157 (7): 512-518. http://dx.doi.org/10.7326/0003-4819-157-7201210020-00514

28. Padeletti, L., Santini, M., Boriani, G., Botto, G., Ricci, R., Spampinato, A. (2007). Duration of P-wave is associated with atrial fibrillation hospitalizations in patients with atrial fibrillation and paced for bradycardia. Pacing Clin Electrophysiol. 30, 961-969.

http://dx.doi.org/10.1111/j.1540-8159.2007.00793.x PMid:17669078

29. Lodish, H., Berk, A., Kaiser, C., Krieger, M., Bretscher, A., Ploegh, H., Amon, A. (2000). Molecular Cell Biology (7th ed.). New York, NY: W. H. Freeman and Company. pp. 1021-1022, 1025, 1045.

30. Rang, HP. (2003). Pharmacology. Edinburgh: Churchill Livingstone. Page 149. ISBN 0-443-07145-4.

31. Callies, C., Fels, J., Liashkovich, I., Kliche, K., Jeggle, P., Kusche-Vihrog, K., Oberleithner, H. (2011). Membrane potential depolarization decreases the stiffness of vascular endothelial cells. J Cell Sci. 124, 1936-1942.

http://dx.doi.org/10.1242/jcs.084657

PMid:21558418

32. Marieb, EN., Hoehn, K. (2014). Human anatomy and physiology. San Francisco, CA: Pearson Education Inc.

33. Gear, K., Marcus, F. (2003). Arrhythmogenic right ventricular dysplasia/cardiomyopathy. Circ. 107: e31-e33.

http://dx.doi.org/10.1161/01.CIR.0000053943.38763.70 PMid:12569915 